\title{
Persuasion in Jesus Christ's Humour: A Linguistic Analysis
}

\author{
Riyadh Tariq Kadhim Al-Ameedi' ${ }^{1}$, Rufaidah Kamal Abdulmajeed ${ }^{2}$ \\ ${ }^{1}$ College of Education for Human Sciences, University of Babylon, Babylon, Iraq \\ ${ }^{2}$ College of Education for Women, Baghdad University, Baghdad, Iraq \\ Email: hajeya2@gmail.com
}

Received 27 February 2016; accepted 3 April 2016; published 6 April 2016

Copyright (C) 2016 by authors and Scientific Research Publishing Inc.

This work is licensed under the Creative Commons Attribution International License (CC BY). http://creativecommons.org/licenses/by/4.0/

(c) (7) Open Access

\begin{abstract}
Believers and non-believers think that religion and humour do not go together well but in fact they are more integrative. Humour has been identified as a pathway to spiritual wisdom. It is rare to find a religion, including Christianity, that does not include laughter and humour in one form or another such as myths, rituals etc. The divine laughter and humour represent the relationship between humans and religions. It is an instrument for putting humans in their place in relation to divine beings. Humour which is not spiritual is of no significance to religion. The present study is oriented primarily towards presenting humour in Jesus Christ's Biblical Verses in the New Testament. A linguistic analysis of selected verses is carried out by searching figures of speech, such metaphor according to Kostler (1964), as a rhetoric device, and how by its flouting Grice Maxims (1975) gives rise to laughter. Besides, following Attardo's (1994) and Raskin's (1985) scripts, the study discusses how the oppositeness of the real/unreal scripts clash and evoke laughter. The results show that humour in these verses is a device of persuasion since the main aim of the process of flouting Grice Maxims by the rhetorical figures of speech is to achieve persuasion.
\end{abstract}

\section{Keywords}

Humour, Religion, Pragmatics, Persuasion, Linguistics Analysis, New Testament

\section{Introduction}

One might think that humour, although it is recognized in almost all religions, has, unexpectedly, rather rarely been studied in a scholarly context. Some scholars believe that religion and laughter are two different human phenomena: “one involved an upturned vision, the other a bodily reaction. Religion seriously addresses ques- 
tions of ultimate concern; laughter is mostly unserious” (Gilhus, 1997: p. 1).

Both "believers and non-believers tend to equate religion with seriousness, profundity, reverence [...] God prefers to be approached in a reverential, dignified manner, not familiar at all. Religion is not an object of ridicule, nor is it ever a laughing matter” (Geybels, 2011: p. 13).

These views and others characterize the thought that religion and humour should not go together well, but they do. Happily enough, they are more constructive and integrative. Humour has been identified as a pathway to spiritual wisdom. It is rare to find a religion that does not include laughter and humour in one form or another such as myths, rituals. The divine laughter and humour represent the relationship between humans and religions. It is an instrument for putting humans in their place in relation to divine beings. Humour which is not spiritual is of no significance to religion.

Many forms of humour emerge in real-life situations with a sudden or unexpected twist that can be intentional or unintentional. "Linguists, psychologists, and anthropologists have taken humour to be a category covering any event or object that elicits laughter, amuse, or is felt to be funny” (Attardo, 1994: p. 4).

Humour is defined by Mindess (1971: p. 21) as "a frame of mind, a manner of perceiving and experiencing life. It is a kind of outlook, a peculiar point of view, and one which has great therapeutic power."

Raskin (1985: p. 1) sees nothing unusual or rare about the phenomenon: "Somebody hears or sees something and laughs. In most cases, this means that the person finds the audial or visual stimulus funny. Funny situations, funny stories, even funny thoughts occur everyday to virtually everybody.”

(Ross, 2005: p. 1) defines humour as "something that makes a person laugh or smile." But like all straightforward definitions, expectations can be found. One might think that something is humorous, even though no one laughs at the time and people might laugh on something that is not funny.

Humour and laughter are universal human expressions and aspect of human experience. They occur in all cultures and all individuals throughout the world practice these human traits. They compose a dividing line between humankind and animals. But laughter is a sign of many different meanings and part of the culture. Different cultures have their own norms concerning the suitable subject matter of humour and the types of situations in which laughter is considered appropriate, but one cannot distinguish the sounds of laughter, as a pattern of vocalization, from one culture to another. Developmentally, laughter is one of the first social vocalizations (after crying) emitted by human infants (McGhee, 1979: p. 3).

\section{Humour in Christianity}

"Jesus of Nazareth is the greatest humorist of all time for three reasons.” By this sentence, Palmer (2001: p. 25), opens his argument and states these three reasons:

First, because of the breadth of what he knows about reality [...]; second, Jesus is good to the core and the greatest humor has always had its source in the good surprise of grace [...]; the third reason will itself take us by surprise. Jesus is the greatest humorist because he is the most normal man we have ever met.

Jesus Christ's humour comes not from confusion but from the clear head and a clear vision of reality. On a wall in the kitchen of the Franciscan Renewal Center in Scottsdale, Arizona hangs a drawing of Jesus Christ titled "The Laughing Christ." It shows Jesus with his head thrown back and his mouth wide open, enjoying a hearty laugh. A priest took the drawing and showed it to an adult education class. One rather grim-faced woman rose and asked, "Where in the Bible does it say that Jesus ever laughed?" "Jesus was once a baby," the priest replied, "and presumably he wet his pants on occasion. Where in the Bible does it say he ever wet his pants?" The woman walked out in a huff (Samra, 1986: p. 3).

There is a universal and widespread failure to recognize and to appreciate an amazing element in Jesus Christ's life which is so important that, without it, any understanding of Him is inevitably distorted and, using the Trueblood's words, "the general misunderstanding is very great, and also because much of the relevant evidence is so deeply hidden by accepted presuppositions that it will not be recognized apart from some analysis" (Trueblood, 1964: pp. 9-10).

Readers of Gospels do not know how much humour there is in Jesus Christ's teaching, but they can be sure that there is far more than is normally recognized as soon as they are liberated from the assumption that Jesus Christ never joked. This relative freedom from presuppositions that Jesus Christ was always deadly serious might lead them to see that He laughed and He expected others to laugh and He was not always engaged in 
pious talks.

Those readers often twist Jesus Christ's words in order to try to make them in conformity with these presuppositions. Christians usually are not accustomed to read Bible in a humorous spirit in which it is written. The misguided piety has made Jesus Christ's believers fear the fact that the acceptance of His obvious wit and humour would be blasphemous. They think that "religion is serious business and serious business is incompatible with banter" (ibid.: 13-4). And they always "think of Him as mild in manner, endlessly patient, grave in speech, and serious almost to the point of dourness" (ibid.).

The second reason for the widespread failure to recognize the humour of the Gospels is their great stress upon the tragedy of the crucifixion and the preceding events. This tragic aspect is intrinsically unhumorous.

Another reason for the failure to laugh is the extreme familiarity with the text and the paradoxical character of what is accepted and common and unexciting.

It is really surprising that many Christians cannot tolerate the image of a joyful, laughing Jesus and Christianity tends to be associated with contemplation the sorrowful Jesus Christ and with the question of whether Jesus Christ ever laughed. Humour of Jesus Christ is one of the neglected aspects of his life. The first thing to do is to overcome this universal failure and to challenge the conventionalized picture of a Christ who never laughed. Trueblood realizes that Jesus Christ was not always engaged in pious talk. He says that anyone who reads the "Synoptic Gospels" with a relative freedom might notice that Jesus Christ laughed and expected others to laugh (ibid.: 13).

The writers of Gospel faithfully wrote down the words of Jesus Christ but "they did not record in writing things like the twinkle in the eye, the gentle smile, the grin, the hearty laugh" (Samra, 1986: p. 7). John said in his Gospel that Jesus Christ said and did a lot of things the Gospels' writers did not record. The personality of Jesus Christ is not completely laid out in the Gospels: "There are still many other things that Jesus did, yet if they were written about in detail, I doubt there would be room enough in the entire world to hold the books to record them" (John, 21: 25).

The fact is that Christians, misguided by the thought that religion means piety, have developed a false pattern of Jesus Christ's character. They think of Him as an endless patient, mild in manner and almost serious and try to explain the Bible verses in a way that is consistent with this picture. The supposed mildness, as Trueblood claims, is to be contradicted by the Christ's stronger epithets He uses to call a man with a worse name as "a white-washed tomb full of putrid and decaying flesh” (Matt. 5:29, 30 and 18:8, 9). This is an instance of divine impatience and nothing of mildness (ibid.: 14). Jesus Christ, using Samra's (1986: p. 4) words, is "the world's most balanced man." He says that the balanced people possess a certain quality of joy and sense of humour and a quality of spontaneous laughing as a small child. "Humour is a balancing, disarming, and therefore peacemaking force that touches on the divine" (ibid.).

The novel The Name of the Rose (Il Nome Della Rosa) in 1980 by the Italian linguist and novelist Umberto Eco (1980) was one of the bestseller novels worldwide and it was the film that popularized its content to a wide audience. In this novel, the writer makes theological discussions whether laughter is permissible or not in a monastery. The main character, the old Benedictine monk Jorge of Bugos believes that humour is devilish. The devil uses laughter to distract monks from their contemplation of God. The novel was about a monk with piety keeps a manuscript which is thought to be lost. This rare manuscript was nothing but the second volume of Aristotle book The Art of Poetry which is devoted to humour. People come from different parts of the country to see this manuscript which is known as a source of happiness for miserable people. The monk does not prevent those people from reading this manuscript but everyone enters the room to read it died immediately. This leads police to make the required inspections and finally they discovered that the monk poisoned the pages of the manuscript and the victims tend to water their fingers to turn the pages of the book by putting their fingers in their mouths. This was the monk's intention to send the victims to death in order not to tell others with the content of this book; that humour and laughter is permitted in Christianity and Jesus Himself laughs several times in the New Testament. The monk was afraid that reading this book leads to the destruction of all Christianity traditions built along centuries.

This attitude may be due to the Church Fathers' disapproval of laughter because, according to them, Christ himself never laughed in the Bible. This attitude can be found in the lives of saints and priests who "abhorred jokes and laughter as children or counted them among sins that should be avoided by a holy man" (Marciniak, 2011: p. 143).

Clement of Alexandria was one of the first Christian thinkers, who devoted a special discussion of laughter in his Paidagogos. He thought that even smiling must be kept under control and laughter must be regulated even if 
it is natural to human beings (Gilhus, 1997: p. 65).

John Chrysostom, Bishop of Constantinople, was known as the first who points out that Jesus never laughed. But, he did not want to do away with all kinds of laughter. He criticized the excess of laughter which is out of control. At Chrysostom's time, there had been a shared opinion among the leaders of the church, the monks and hermits who renounced the world, that laughter challenged virtue and led to carelessness (ibid.: 67).

One century passed, the Benedictine Rule forbade laughter and said "speech provoking laughter, we condemn everywhere to eternal exclusion" (cited in Joeckel, 2008: p. 416). Later on, Baudelaire in the nineteenth century admitted that "the Bible, not without cause has been called the world's least amusing book, a sober-minded tome whose black covers convey its essential mood and vision” (Wood, 1988: p. 1).

Yet there have been some changes over time. "Moderate monks state that there is no problem with a small smile, but a very strong objection to laughing out loud. This kind of laughing must be punished. This will remain the state of affairs for centuries: only a modest smile is allowed” (Geybels, 2011: p. 14). Joeckel (2008: p. 417) mentions the first occasion of intersection between Christianity and humour. During Holy Week (the week before Easter) "paschal laughter" was allowed in the church. The priests, as (Bakhtin, 1994 [1981]: p. 72) says, were involved in "risqué' jokes and gay-hearted anecdotes from the church pulpit in order to encourage laughter in the congregation - this was conceived as a cheerful rebirth after days of melancholy and fasting." Another humorous festival documented by Bakhtin (ibid.) is the "Christmas Laughter" in which "serious church hymns were sung to the tunes of street ditties and were thus given a new twist."

These instances marked a turning point in Christianity. Christians are no longer humourless. Humour attained new religious significance and laughter acquired symbolic value. There are arguments available to support that Jesus liked a bit of humour. "Humour is a key concept in the actions of Jesus" (ibid.: 16). It is His way and His ideal method of delivering His message without moralizing.

A laughing Christ appears in ancient Coptic texts found in Nag Hammadi in Upper Egypt in 1945. The texts said that: "The living Jesus is glad and laughing above the cross while nails are driven into the hands and feet of his substitute, as well as, a laughing Christ appears in the newly found Gospel of Judas, likewise from Egypt. This kind of laughter, at first glance, seems to be a happy laughter” (Gilhus, 2011: 123).

The New Testament is filled with this kind of humour that is intended to respectfully communicate many claims and truths. The story of the adulterous woman in the gospel of John (8: 1-11) is widely known where Jesus Christ gives His ironic answer and asks that whoever is without sin should cast the first stone, whereupon his audiences make their retreat.

In the middle ages and the renaissance, the importance of humour is increased. The medieval Church celebrated "Twelfth Night", "the first day of Epiphany, the day that marks Christ's baptism. Celebrations involved riotous revelry, a festival analogous to modern-day Mardi Gras, a time when social conventions were turned upside down" (Joeckel, 2008: p. 417).

Laughter, pious or not so pious, flourished. It is "introduced into the sacred presence of the suffering body of the savior and the holy sacrament of bread and wine" (Gilhus, 1997: p. 83). As the popular feast flourished, the status of laughter and its usefulness also became a subject of comments among the church leaders. Some supported the traditional stand of the early church and the others were more broadminded and allowed kind mockery and mild mirth (ibid.: 84). Bakhtin (1968: p. 75) names them the "inventive priests" who told the authorities that feasting is necessary because 'foolishness' is the human's second and inherited nature in man and need to be spent at least once a year.

In the twentieth century, several authors have found a passing reference to the humorous side of Jesus Christ's teaching, as Harry Emerson Fosdick puts it, "He never jests as Socrates does, but He often lets the ripple of a happy breeze play over the surface of His mighty deep” (cited in Trueblood, 1964: p. 23).

In modern western societies, religion has a great entertainment potential. The new interplay between religion and laughter is found in modern novels, films, popular magazines and scientific literature. "Underneath all these examples lies a conception of laughter where it is seen as a positive contributor to human liberation, spiritual growth and wisdom” (Gilhus, 1997: p. 109). It is a source of relieving tension and helping to cultivate a playful attitude toward life. The twentieth century has witnessed a general tendency to include concepts, images and references taken from religion when describing the positive value of laughter (ibid.: 110).

\section{Humour as a Device of Persuasion}

This section focuses primarily on the important role humour has played as a persuasive strategy from a prag- 
matic approach. What follows explicates in detail the connection between humour and persuasion as two complimentary concepts.

To accomplish persuasion, rhetorical devices presented by specific figures of speech should be available. A figure of speech, as defined by Levinson (1983: p. 109), is an artful 'deviation.' It shows a sort of deviation from conventional communication either in form or in content. Levinson's deviation from norm means to flout (a) maxim(s) of conversational interaction which, in turn, gives rise to many pragmatic figures of speech.

Figures of speech are classified into two types: Schemes and Tropes. The figures of speech in the tropic mode involve a deviation from the ordinary and principal signification of words. Examples of tropic figures of speech are: pun, metaphor, hyperbole, overstatement, understatement, and rhetorical question (McQuarrie and Mick, 1996: p. 3).

They (ibid.: 6) define tropes as figures of speech that do not provide the recipients with complete information. They cause vagueness and ambiguity and produce implication that requires the recipients to infer the intended message.

The rhetorical pragmatics of metaphor and pun depends on flouting the maxim of quality, using (Davis, 1998: p. 12) words, as well as, they intentionally flout the maxim of quantity as truthfulness is deliberately violated.

According to Aristotle in his Rhetoric, metaphor, among other types of tropes, is the main part of rhetorical strategies aiming at accomplishing persuasion (Murphy, 2006: p. 864). Aristotle defines rhetoric as the faculty of observing in any given case the available means of persuasion. Persuasion, as the main aim of rhetoric, is accomplished through the use of three "proofs": ethos, the credibility of the speaker; pathos, the emotions of the audience; and logos, the arguments used (ibid.).

The term "persuasion" has been defined differently by so many linguists and scholars corresponding to their interests and purposes. It can be defined linguistically (apart from psychologically that will be discussed below) as the use of language in an intended communicative way that affects how others think, feel, and/or act toward some object, person, group or idea (Cegala, 1987: p. 13). The main aim of persuasion is to build personal ties with the audience and to establish and maintain social connection between the speaker and the recipient. Thus, persuading the audience is closely engaged with rhetoric.

Recent rhetoricians, like Kennedy (2007: p. 7), Walton (2007: p. 2), and Dave (2008: p. 12) agree that "rhetoric" is a strategy designed to persuade a targeted audience. In fact, "rhetoric has at times been understood simply as the study of persuasion” (Herrick, 2012: p. 3). It is not the way of deceiving people but, rather, as Kennedy (2007: p. 27) argues, that even those who have faith in their objectives and try to establish justice and truth are in need to rhetoric when they face the public audience. Thus, rhetoric is not a means of misleading the audience but a means of reaching truth and confidence. Many linguistic choices are available in rhetoric to communicate thoughts and to attract the audience and to convince and persuade them within a particular context. Walton (2007: p. 5) claims that the use of language for specific reasons, as to persuade or attract someone, is an argument and classified under the study of rhetorical pragmatics.

The psychological approach of persuasive discourse as defined by Lakoff (1982: p. 11) is the nonreciprocal "attempt or intention of one party to change the behavior, feelings, intentions, or viewpoint of another by communicative means." Later Lakoff (ibid.: 28) puts further condition for the text to be persuasive by saying that "unidirectionality in communication is a sufficient requisite to define a discourse as persuasive."

It is useful to mention here the two concepts proposed by Tannen (1990: p. 520), namely, "power" and "solidarity". She believes that "dominance cannot be correlated with linguistic strategies." This attitude contradicts the humour found in religious texts. The speaker in religious texts "will make an effort to be in a solidarity status with his audience in an attempt to overcome the rejection that the public may feel [...] and the way to achieve it is through humour" (Arroyo: online). Tannen thinks that "the solidarity with the audience springs up from the use of humour [...] thus power dissolve into solidarity” (ibid.).

Perloff (1993: p. 184), on the other hand, raises the following question: Does humour facilitate persuasion? and answers it saying that it "depends on the type of effect a persuader wishes to achieve."

Humour, according to Perloff (ibid.), is injected and employed in various types of speeches in order to attract the attention of the hearers. He gives examples from advertisements, public relations, and presidential campaigns. In presidential campaigns, he says, consultants are hired to prepare jokes and inject humour into the persuasive speeches of the contesters. He concludes that "there is strong evidence that injecting humour into a persuasive message helps get people's attention” (ibid.).

The audience responds to persuasive messages, as Mills (2000: p. 2) suggests, in two ways: thoughtfully and 
mindlessly. We listen thoughtfully when we listen carefully to what the persuader is saying, and we respond to the messages mindlessly when we do not have the time, motivation, or ability to listen. He further suggests that "professional persuaders know humour can be a powerful tool." He cited Herbert Gardner saying: "once you've got people laughing, they're listening and you can tell them almost anything." He cited the speech of the humour consultant, Malcolm Kushner, when he says: "Humor is a powerful [...] tool, it can gain attention, create rapport and make a message more memorable. It can also relieve tension, enhance relationships and motivate people, if it is used appropriately" (ibid.: 130).

Figures of speech can be viewed from different linguistic fields such as phonology, syntax, and pragmatics. The figures of speech that are appropriate for this study are the pragmatic ones in that they are characterized by flouting the conversational maxims within particular contexts and cause an indeterminate meaning in their context.

To associate religious humour with persuasion is an innovative contribution in this study. Jesus Christ, in His speeches, is not saying words in vain and does not cast words aimlessly. Every single word said by Him and comprehended and perceived by His followers has its own aim and function. Therefore the main function of humour in this kind of discourse is persuasion.

\section{The Model of the Analysis}

The model of the analysis will eclectic. It will consist of:

1) MEATPHOR from Koestler's (1964) theory, who believes that metaphor is the main reason for evoking laughter, on the semantic and pragmatic levels will be one tool in this eclectic model of analysis of this study. Lakoff and Johnson's (1980) theory of "conceptual metaphor" will be adopted in this model. It operates on the level of thinking and linking the "source" domain and "target" domain. The "source" domain consists of literal entities called "lexical sets", stored in the mind, linked semantically and are expressed in language through words and expressions organized and related to each other as groups. The "target" domain is an abstract entity takes its structure from the "source" domain through the metaphorical link. The entities in the "target" domain are lexicalized by using words and expressions from the "source" domain.

2) SCRIPT from Raskin's (1985) and Attardo's (2001) theories on the semantic level will be used as another constituent of the model of the analysis. Throughout revising the language of the contemporary linguistic theories of humour, the following four terms are found: a) Koestler's (1964) Bisociation, which means "blending of elements taken from two previously unrelated matrices of thought into a new matrix by means of comparison, abstraction and categorization, analogies and metaphor;" b) Raskin's (1985) Script, which means "schema" or "frame" or temporal sequence of frames and every word of the sentence evokes a script or scripts with which it is associated and contains typical information about well-established routines and common ways to do things; c) Attardo's (1994) isotopy, which consists of two elements that cause the shift from one to the other and set off laughter. These elements are "disjunctors" which operate closely with the "connectors". Disjunctors cause the passage from (isotopy 1) to (isotopy 2) and the connectors provide justification for transition; and d) Attardo's (2001) Storage area, which is an empty sentential script filled by the lexical and inferential scripts activated by the text and then uploaded in the storage area and connected to the other scripts already stored there. These four terms are different labels for the same entities. They share common features; namely two contradicted schemas, one is normal and real and the other is not normal and unreal and functions as the trigger of laughter. Therefore, the researcher coins a new term out of these four terms under the name of STORAGE SCRIPT in analyzing the humorous data of this study and adopt Raskin's definition of a script: "a text can be characterized as a funny if both of the following conditions are satisfied. i) The text is compatible, fully or in part, with two different scripts. ii) The two scripts with which the text is compatible are opposite." to be the base of the analysis of storage scripts of the data of the analysis.

3) On the pragmatic level, GRICE'S MAXIMS from Raskin's (1985) and Attardo's (1994) theories will be adopted as a part of the model of the analysis of the current study. Flouting these maxims by the speakers will be the base of the analysis of the texts to see how flouting of these maxims evokes laughter. Grice's framework fits for dynamic interaction which implies that this theory could be useful in analyzing humour texts arising from such interaction.

Grice generalizes four maxims from the Cooperative Principle (henceforth CP). They are respectively:

Maxim of Quantity: 
1) Make your contribution as informative as required for the current purposes of the talk exchange.

2) Do not make your contribution more informative than is required.

Maxim of Quality:

1) Do not say what you believe to be false.

2) Do not say that for which you lack adequate evidence.

Maxim of Relation:

1) Be relevant.

Maxim of Manner:

1) Avoid obscurity of expression.

2) Avoid ambiguity.

3) Be brief.

4) Be orderly.

(Grice, 1975: pp. 45-46).

He assumes that the participants in any conversation must follow these maxims and try to cooperate with each other to achieve a successful communication.

Maxims and flouting are two closely interrelated terms. Flouting maxims is a blatantly breaching of one of the maxims because hearers are expecting the speaker to be faithful and cooperative, i.e. observes the maxims. This notion is used by large in humour studies. As such, the term 'flouting' is going to be used in our text analysis.

Grice (1975: pp. 41-58) identifies four flouting possibilities:

1) The flouting of the maxim of quantity takes place when the speaker blatantly provides inadequate information and gives more information than the situation requires. This insufficient information gives rise to humour.

2) The flouting of the maxim of quality takes place when the speaker blatantly says something untrue or for which shelhe lacks adequate evidence. In humorous talks, the speaker may exaggerate some realities to achieve comical effect.

3) The flouting of the maxim of relation comes about by making a response or an observation which is very obviously irrelevant to the ongoing talk exchange. An irrelevant response results in humorous talks.

4) The flouting of the maxim of manner occurs when the speaker does not avoid obscurity and ambiguity. Since ambiguity is a common linguistic phenomenon, so it is hard to be fully observed. Nevertheless, when ambiguity is used in certain contexts, the hearer may deliberately distort what the speaker has said to convey extra message.

\section{Data Analysis}

Ten Biblical Verse are selected from the New Testament will be the subject of the analysis according to the eclectic model of this study:

1) 29 If your right eye causes you to sin, gouge it out and throw it away. It is better for you to lose one part of your body than for your whole body to be thrown into hell. 30 And if your right hand causes you to sin, cut it off and throw it away (Matt. 5: 29-30).

a) Storage Scripts: The two opposite schemata are: the first is triggered by words "right eye", "body", and "right hand". These are constituent parts of the body of normal human being. This script of a real situation is stored in the mind of hearers referring to a small part of the world. It is opposite to the other script which shows a human being without right eye and left hand, i.e. an incomplete human body. These incongruous images evoke laughter because the second one is in opposite to the hearer expectations. The second reason for laughter is when we imagine someone is pulling his eye and chopping his hand as a symbol of preventing himself from committing sins. The cruelty and the impossibility of the action trigger laughter.

b) Flouting Grice's Maxims:

i) The maxim of quantity is flouted when Jesus Christ does not give direct instructions to stop committing adultery. He gives images of cutting parts of the human body as a means of hindering someone from committing sins. These long and exaggerated views give rise to laughter.

ii) Amputating one's body cannot cure lust. It is impossible for human being to pluck his eyes or had his hands chopped. By this metaphorical untrue sentence, Jesus Christ flouts the maxim of quantity. How can one live his normal life with half body or even think of practicing his desires?

iii) Concerning relation maxim, the speech is irrelevant to the ongoing talk exchange. How can one stop him- 
self from responding to sins by pulling his eyes and cutting his hand?

iv) As for the maxim of manner, this speech is said figuratively by employing metaphor which makes a point through an exaggerated statement. Exaggeration produces an extra message, thus, obscurity occurs. He refers to the possibility of mind's eye which is the most dangerous since evil arises in the heart (bible.org: online).

c) Metaphor: The source domain is that someone tries to prevent himself from committing sins. Sins are committed by hands and eyes. The target domain is that he thinks of chopping his hand and pulling his eyes in order to stop his desires. The two images are related semantically. Hindering oneself from doing unlovable things is exemplified by chopping those parts which are responsible for doing these ugly things. Jesus Christ does not mean that people should actually remove their eyes or hands. This picture is said metaphorically. People want to do wrong things so they try to remove their body parts that cause these sins. It might be painful to remove these parts of their bodies but that would be better for them than to destroy their whole life.

2) 1 "Be careful not to do your "acts of righteousness" before men, to be seen by them. If you do, you will have no reward from your Father in heaven. 2 So when give to the needy, do not announce it with a trumpet as the hypocrites do in the synagogues and on the streets, to be honored by men. (Matt 6:2)

a) Storage Scripts: The first script or a real situation script is internalized and shared by native speakers is related to a man of charity who distributed alms to the poor. At that time the poor were gathered by tapping a trumpet. This normal schema is triggered by the words "act of righteousness", "reward", and "needy". The second unreal script which is partially compatible with the first one and which has the comical effect is a man doing his charity works with parade or public ceremony having trumpet making loud noise to attract other's attention to be praised by them as hypocrites. This funny script evokes laughter on the trumpet of the hypocrites which is in opposition to the script of man of piety who spends his money where his left hand does not know what his right hand is doing.

b) Flouting Grice's Maxims:

i) The flouting of maxim of quantity takes place in this verse when Jesus Christ provides inadequate information about the hypocrites. The relation between trumpet and hypocrites is not clearly manifested.

ii) The script of man of piety is always referred to as a man whose ultimate aim is making good deeds and helping the poor. This metaphoric image of a man with trumpet is not a true image of a man of charity. It refers to a man of hypocrisy.

iii) The word 'trumpet' is totally irrelevant to the ongoing talk. Charity needs no trumpet. This metaphoric connection between the needy that were collected by tapping on trumpet and the hypocrite deeds of those who want mass media to let others know what is going on. The verse is about doing righteousness acts for the sake of God.

iv) The maxim of manner is flouted by the word 'trumpet'. It entails the occurrence of obscurity as a result of metaphor and in turn it gives an extra message.

c) Metaphor: The figurative language is clearly used here. Doing good things with a desire to publicize it to let others know in order to praise the doer is just like holding a trumpet walking in the street shouting to announce this deed. The source domain is of men of charity using trumpet to call the poor in order to be gathered and receive the alms. This image is connected with the target domain of using trumpet by men of hypocrisy as a means of announcing their good deeds. The noise of the trumpet is the link between these two images.

3) Why do you look at the speck of sawdust in your brother's eye and pay no attention to the plank in your own eye? 4 How can you say to your brother, "Let me take the speck out of your eye," when all the time there is a plank in your own eye? (Matt 7: 3-4)

a) Storage Scripts: The first script contains a bundle of semantic information internalized in the repertoire of the hearer that human beings have eyes in their faces as a normal creature. This is the usual and normal image of humans. This script is evoked by the words "eye" and "brother's eye”. The sense for the script opposition, in the second script, is triggered by the unreal situation where a human being with a large beam or plank in his eyes. The first script describes a certain real situation and clashes with another unreal situation which is fully or partially compatible with the text. It is humorous for a man to be so deeply concerned with unexpected image of a speck in another person's eye. Human's eyes are not large enough to have a beam in them. The idea is ludicrous. It rebukes laughter.

b) Flouting Grice's Maxims

i) The maxim of quantity is blatantly flouted in this text. It contains inadequate information. How can a plank or a beam be in the eyes of a man and this beam can be imagined as a large piece of wood. 
ii) The flouting of maxim of quality takes place when Jesus Christ uses metaphoric exaggeration of some realities. This metaphoric image achieves ludicrous. A small place of flesh and blood and soft tissues in the face of human being can host a large piece of wooden bar. This unreal situation evokes laughter.

iii) This image of wooden bar in the eyes of a man is irrelevant to the ongoing talk. Jesus Christ intends to advice His followers to try to amend their behaviours before reforming others' behaviours. This advice might be said without the mention of sawdust and wooden beam.

iv) The obscurity and metaphor are obviously flouting the maxim of manner. Jesus Christ is not clear and to the point in issuing His advice.

c) Metaphor: Jesus Christ uses the word "brother" not in its literal meaning as a brother in one's own family but as a person who believes in Jesus Christ so he becomes a member in God's family.

The expression "speck of sawdust" and the word "plank", which are opposite in meaning and in physical size, can be explained metaphorically as why one with the face that can criticize others for smaller faults, while he/she is guilty of much greater sins and is neither sensible of them nor has the intention of amending them. The source domain is that a man with a burden of sins and he does not care about these sins and does not pay an attention to his personal flaws, inversely, he looks for other faults. Just like, as in the target domain, a man who has a heavy piece of wood in his eye that makes him unable to see at all and at the same time, instead of curing his eye, he strives to remove a tiny bit of dust from another person's eye. This stupidity would make people laugh on this humorous picture.

4) Leave them, they are blind guides. And if a blind man leads a blind, both shall fall into a pit (Matt 15:14).

a) Storage Scripts: The two overlapping opposite scripts evoke laughter. The first script is a real situation triggered by the word "guide" as a schema stored in our minds of a man who should have opened eyes to lead others to the right way and take them to their destination. It is an unmarked script and the most frequent one. The second is the marked script which describes certain unreal situation. It is opposite to the expectation of the hearer. One cannot imagine a blind guide doing his job in the right way. This opposite script is triggered by the word "blind", "guide", "fall” and "pit". Of course, if the blind guide leads a blind man both will necessarily fall in troubles exemplified by the word "pit".

b) Flouting Grice's Maxims

i) The maxim of quality is obviously flouted by means of providing inadequate information. How can a blind man lead another blind man? No further explanation is given to understand this unreal image. Unhumorous preceptors find it unhumorous. Such paradoxical humorous saying is subject to a means of selection among hearers which do not hear and do not understand.

ii) The metaphoric image used in this verse flouts the maxim of quality. The absence of truthfulness is necessarily acted as the basic ground for flouting the maxim of quality. Jesus Christ's employment of paradox of the blind leading the blind is absurdity in which there is a hint of laughing.

iii) An obvious flouting of the maxim of relation takes place by the action of leaving two blind men which is an irrelevant statement with the rest of the verse. Leave them they are blind instead of saying guide them they are blind. Literal minded people are misled by this saying.

iv) The vagueness and ambiguity are aroused by the metaphoric image used in this verse. It lacks clarity and it pushes the hearer to interpret an extra message from the utterance.

c) Metaphor: The metaphoric image is quite clear in this verse. The source domain is the teachers who do not know anything and they are ignorant, therefore, they cannot teach their students, who in return become ignorant because they learn nothing from their teachers. The target domain is corresponding with the set of linguistic expressions in the source domain in that the foolish teacher is similar to a blind man, and ignorant students are also like the blind. And if the teacher who is blind leads other man who is blind too, they will both fall into a pit, as a symbol of troubles. This metaphoric image evokes laughter. One can imagine a blind man leading another blind man and they are walking together seeing nothing in front of them, the result will be necessarily a comical event.

5) But Jesus turned, and said unto Peter, "Get behind me, Satan! You are a stumbling block to me; you do not have in mind the things of God, but the things of men" (Matt 16:23).

a) Storage Scripts: The two overlapping schemata are triggered by the word "Satan". The real and usual image of Satan is the evil spirit that is the adversary of humanity. His main interest is making temptation to humans to get them away from God's way. The opposite image which is incongruous with the first one is that a human being has the portrait of Satan. He looks like Satan from inside and outside. This unexpected image has no roots in our minds. It is an unmarked script which describes unreal situation. We have not ever in our life met a Satan 
or see a man who looks like Satan in form and content. These oppositeness and unexpectedness work together to evoke laughter. The word "Satan" is used in everyday language to refer to the evilness of humans, not in form but in content.

Even His disciples who were supposed to be His faithful followers and were not adversaries come to be subject to Jesus Christ's banter. As it is shown in the first verse, Jesus Christ gives Simon a nickname as Peter and here called him Satan. The probable reason is that he failed to follow his master. Laughter here is the best weapon in such incident. He uses satirical sort of name.

b) Flouting Grice’s Maxims:

i) The flouting of maxim of quantity takes place blatantly when Jesus Christ provides inadequate information. The informativeness is absent here. His answer to Peter is but one word.

ii) The flouting of maxim of quality takes place with existence of metaphoric image of Satan and how this word is used as a symbol of the devilish conduct of Peter. It is not true to tell somebody that she/he is a Satan. There is no evidence.

iii) The maxim of relation is flouted when Jesus Christ tells Peter he is "Satan" because he was telling them about the will of God that He will be killed and then return to life after three days.

iv) The maxim of manner is clearly flouted when Jesus Christ does not avoid obscurity and vagueness. He uses purposeful ambiguity with the metaphoric image of Satan.

c) Metaphor: Metaphor is used here by the word "Satan". The linguistic expression in the source domain stored in the mind is linked semantically with the target domains. Satan as a lexical entity refers to the evil spirit and the devilish creature is related to the metaphorical expressions in the target domain which refers to that man whose conduct is full with evilness and wickedness, he can be described as a Satan. This kind of exaggeration of some realities achieves comical effect.

6) And again I say unto you, It is easier for a camel to go through the eye of a needle, than for a rich man to enter into the kingdom of God. 25 When the disciples heard this, they were greatly astonished and asked, "Who then can be saved?" 26 But Jesus looked at them and said, "With men this is impossible; but with God all things are possible" (Matt 19: 24).

a) Storage Script: if the text is compatible fully or in part with two scripts and these two scripts are opposed to each other, then the text will be funny. This statement can be applied to this verse. The first real situation script is triggered by the words "eye" and "needle". The image of moving the reel or the threads through the eye of the needle is stored in the repertoire of the hearer. The thread is so thin that can be moved easily into the eye of the needle. The second script of unreal situation is of a camel going through the eye of the needle. This statement should not be taken literally. It is an image of impossibility. But portraying such impossible image evokes laughter for no one can imagine a camel with its big size to come through an eye of the needle.

b) Flouting Grice's Maxims

i) The maxim of quantity is obviously flouted when drawing this image of impossibility without giving any explanation of the meaning.

ii) The maxim of quantity is flouted by the employment of metaphor. The speaker needs evidence to prove the possibility of the occurrence of this image.

iii) The maxim of relevance is also flouted. How can a connection be drawn between a camel going through the eye of the needle?

iv) The maxim of manner is flouted because the speaker does not avoid obscurity. This obscurity is represented by the way by which a camel moves through the eye of the needle.

c) Metaphor: The source domain is the rich are difficult to enter heaven. This source domain is linked semantically with the target domain by a set of lexical entities. These lexical entities and expressions will be used metaphorically. The entrance of the rich to heaven is as difficult as the entrance of the camel through the eye of the needle.

7) Ye blind guides! You strain out a gnat, but swallow a camel (Matt 23: 24).

a) Storage Scripts: The two overlapping schemata are the usual one with the picture of swallowing food in normal size that suits the size of human's mouth. This picture is stored in the minds and is triggered by the word "swallow". It is the unmarked script and the most usual one. The other marked and unexpected picture which gives rise to laughter is the one with a man and he is trying to open his mouth widely enough to swallow a camel with its parts and its size which is far bigger than the human's mouth size. The second comical schema is triggered by the words "swallow" and "camel” which is the unusual image. 
b) Flouting Grice's Maxims

i) The maxim of quantity is flouted by the lack of information about how for a human being swallows a camel.

ii) The metaphoric and exaggerated image works to flout the maxim of quality. It lacks truthfulness.

iii) The relevance of this metaphoric image with the ongoing speech is not clear.

iv) It is an obscure and ambiguous image of getting tired of a moth which is so small, but swallows a creature with its abnormal size in comparison with the human size.

c) Metaphor: It is so clear. The surface manifestation of the concept of "swallow" expressed linguistically as a literal entity is moved from the source domain which is its normal context of swallowing kinds of foods to the target domain in which it is used metaphorically. The connection between the two domains is that some may be tired of small things, they cannot resist it, but they are ready to endure heavy and difficult troubles. Jesus Christ says that Pharisees are tired of a gnat though it is so small but they can swallow a camel. How can one imagine himself being able to swallow a huge camel? How can a blind person guide another person? Blind and guide do not naturally fit together. So it is funny.

8) But understand this: if the owner of the house had known at what time of night the thief was coming, he would have kept watch and would not have let his house be broken into (Matt 24: 43).

a) Storage Scripts: The text is partially compatible with two opposite scripts. The first one is the one which is stored in our minds of thieves breaking through the houses causing damages and killings. It is triggered by the words "thief”, "night”, “come in', and "break through". In this case, the usual case, the house owner, of course, does not know when and how the thief comes to his house. This script is overlapped with the other unreal script that the owner knows the time of the thief's arrival and the way by which he is coming inside the house so he will be ready to prevent him. The laughter is evoked by this image. The house owner is sitting day and night waiting for the thief to come in his house without knowing when and how the thief would come.

b) Flouting Grice’s Maxims:

i) The maxim of quantity is clearly flouted by the unreal situation. The text is uninformative. The hypothetical sense found in this verse gives no adequate information. Jesus Christ hypotheses that if the owner of the house knows when the thief is coming, he would do something. The fact is neither the owner nor the thief behave accordingly.

ii) The maxim of quality is flouted because the text provides metaphoric comparison between the thief coming in a house suddenly and the arrival of Jesus Christ back to earth. This kind of comparison achieves comical effects.

iii) Maxim of relation is also flouted in this text. Jesus Christ makes clear how He will come back to earth suddenly. He tries to explain this image with the breaking of the thief into the house.

iv) The maxim of manner is manifestly flouted by providing hypothetical statement. The sentence starts with "if" means that it is not an actual occurrence of the event.

c) Metaphor: The source domain is that the owner of the house would like to know the time of thief at which he comes in order to be ready for him and to prevent him from breaking through the house.

The target domain which is associated with the source by metaphoric expression is the returning of Jesus Christ to earth which will be in the same way of the thief breaking through the house at night. The comparison is not in the bad sense. The thief coming into the house causes destruction and killing, but Jesus Christ's coming is like that of a thief only in the manner; secretly, suddenly and without any previous notice. Therefore, one should be ready for His sudden coming just as the case of watching and keeping an eye on a thief. It is sly insertion. In the middle of serious discourse, the theme is lightened by the observation. Jesus Christ delights us by a fresh statement of the obvious.

9) Suppose your son asks you for bread. None of you would give him a stone. 10 Or suppose he asks you for a fish. None of you would give him a snake. 11 You may not be good people. But you know how to give good gifts to your children. Your Father who is in heaven is good. And he gives good gifts to all those people who ask him!' (Matthew 7: 9-11).

a) Storage Scripts: The two overlapping scripts are opposite. The first script is triggered by the words "son", "fish", and "bread". If a son asks his father a food he will give him as he wishes. The father does not behave in a way that causes harm to his son. This is the normal script stored in the mind of the reader/hearer. The opposite and the unexpected script is triggered by the words "stone" and "snake". The surprising contradictory is when a child asks his father to give him bread, instead, he gives a stone and a snake. This unexpected oppositeness be- 
tween the images evokes laughter.

b) Flouting Grice's Maxims:

i) The maxim of quantity is manifestly flouted. Flouting takes place when Jesus Christ does not provide adequate information. There is no relationship between bread and stone, and fish and snake.

ii) The flouting of maxim of quality is realized by the metaphoric image of bread: stone and fish: snake. Metaphoric images are literally false, thus this text lacks truthfulness.

iii) Bread is irrelevant to stone and fish is irrelevant to snake. If someone feels hungry, he would eat bread and fish at that time, not stone and snake.

iv)The vagueness and lack of clarity may be achieved by means of metaphor. It gives rise to banter.

c) Metaphor: The source domain expressed by the lexical items (food, fish, bread) is moved from their normal context to the target domain in which they are used metaphorically. Father here represents God. When the worshipers ask God to give them what they want, He will answer them in a way that will be in their benefit. The target domain is a father taking care of his children and when they are hungry he does not give them stone and snake instead of bread and fish. Stone and snake represent bad things. So He will not give them what hurts them.

10) And another man, who was one of his disciples, spoke to Jesus. "Lord, first let me wait until I bury my father", he said. 22 But Jesus told him this. "Follow me. Let dead people bury their own dead people" (Matthew 8: 21-22).

a) Storage Scripts: The two opposite and overlapping scripts are: The first one is triggered by the words "bury" and "father". It is quite normal and a well-known schema in our minds to see a live son burying a dead father. This real script is overlapped with the second script of dead people burying dead people. It is triggered by the words "bury" and "dead". This oppositeness evokes laughter. How can dead people bury another dead people? Jesus Christ stimulates this man to respond to God's appeal to follow Him and answer His messenger's calls. Even if his father is ill and he is going to die soon, this should not stop him from following Jesus Christ. Those who remain and do not follow the messenger are considered dead because their heart is not enlightened with faith and piety. So let them, the dead, bury the dead father.

b) Flouting Grice's Maxims

i) The maxim of quantity is blatantly flouted when Jesus Christ provides inadequate information. There is no way of imagining a dead person burying another dead person. This text lacks informativeness.

ii) The maxim of quality is flouted by the metaphorical image of a dead burying a dead. No truthfulness is recognized.

iii) The maxim of relation is obviously flouted when Jesus Christ says "follow me and let the dead bury the dead".

iv) The manner in which this text is said shows a clear flouting of the maxim of manner. The ambiguity and the obscurity are clearly expressed. This vagueness gives rise to laughter and banter.

c) Metaphor: The source domain is expressed by linguistic entities (dead, bury) are moved from their normal context to match the target domain. The second "dead" in "let the dead bury the dead" refers to those men who do not follow Jesus Christ. They are spiritually dead.

Jesus Christ had a revolutionary message to give and He knew that He could not make Himself understood by speaking mildly. He tended to use overstatements and employed an amount of shock to make people break through their deep obtuseness. He felt that the mild language would not have been as successful. This verse is an illustration of "A would-be follower seeks to excuse himself for what seems to us a justifiable reason: he has to bury his father. Jesus Christ, apparently tired of excuses, blurts out, 'Leave the dead to burry their own dead; but as for you, go and proclaim the kingdom of God'” (Trueblood, 1964: p. 47). The metaphor here is a clear means of making a point.

\section{Results and Discussion}

The results of the analysis show that Jesus Christ uses metaphor as a humorous rhetoric device. Metaphor among other figures of speech proves to be the main constituent of humour and is highly effective in provoking laughter. It scores 10 times out of 10 Biblical Verses in 100\% percentage. Metaphor, suggested by Koestler (1964), causes much fun. It is prominent in the speeches of Jesus Christ. The humour of Jesus Christ as a result of metaphor appears clearly to the readers who are familiar with these Gospels.

The employment of metaphor is necessarily the cause of flouting one or more of Grice's maxims. Whenever 
there is metaphor, there is, at least, flouting of maxims of quality and manner.

As far as pragmatics is concerned, in the course of the analysis, it has been shown that flouting Grice's maxims is employed heavily, thus humour can be explained by the exploitation of pragmatic aspect. Quite often, humour is generated by exploiting features of Grice's maxims. Flouting of Grice's maxims takes place by the appearance of metaphor as a rhetoric device.

As established by Grice, flouting of maxim of quantity comes from providing less information than necessary. The absence of details triggers incongruity because it prevents the hearer/reader discovering the relationship given in the text at once. This relationship remains incongruous until the hearer/reader perceives all the data that will help him to interpret the message correctly.

The maxim of quality, as Grice says, it is associated with lies, requires truthfulness. The absence of truthfulness takes place with occurrence of metaphor.

The maxim of relation is frequently flouted as a consequence of giving irrelevant information. Thus the interpretation of the meaning of the text will be totally different from what is being said.

Lastly, the maxim of manner is flouted by means of ambiguity and again by metaphor, as a rhetorical figure of speech, which is used for achieving persuasion.

Humour in these verses arises from schema clashes. The merit of this approach is that it enables the reader/hearer to account for their knowledge-based inferencing ability and how they use this ability to process humorous texts. The reader/hearer comprehension of the text is guided by schemata, which, once activated, offer a further chance to make knowledge-based inferences.

The researcher concludes that the function of humorous language in religious texts is persuasion. Religious discourse, among other types of discourse, is an obvious example of persuasive discourse. The receiver's response to the message issued does not take place in an oral or written answer, but it is embodied in the acceptance of the message that is carried by the Biblical Verses, i.e. a hidden positive reaction.

From this discussion, the researcher arrives at the conclusion that the principal function of humorous language used by Jesus Christ is to persuade His followers of the message He conveys with mild language and joyous spirits as well as with His personality as a normal human being sharing all human beings' instinctive characteristics. He admitted His instincts with which God created Him. God has created Him rejoicing, laughing and playing, as well as crying, weeping and feel sadness.

\section{Conclusion}

One can argue that humour should facilitate persuasion by means of "distracting people from thinking up counterarguments to the message, by putting them in a pleasant state of mind, or even by increasing their physiological arousal” (Duncan and Nelson, 1985, cited in Perloff, 1993: p. 185). This means that people's attitudes come to be changed under the impact of humour. Evidence shows that humour has a great impact on attitudes. People receive humorous message better than reading it seriously.

The best of all we need is to laugh because life is exciting and the source of happiness is as joyous as it is serious. We need to laugh because people can be hurt by what happens while living. God creates us with a selfconsciousness which makes grief possible but God also makes us able to laugh and thus to provide a balance to our danger.

Some people oppose laughter especially in religion because they think that it is inappropriate and even sacrilegious. They are shocked at the idea that there is any connection between God and comic spirit. They are called laughter-haters. For those we say that this kind of humour heals. It does not hurt too much if the person has enough insight and objectivity to laugh. Laughter can be redemptive and it is that which goes beyond scorn.

The logical mistake arises when we suppose that the Jesus Christ's sadness necessitates a denial of His humour. It is not like satire but it is a kind of politeness, nearer a smile and no more than a smile.

\section{References}

Attardo, S. (1994). Linguistic Theories of Humor. New York: Mouton de Gruyter.

Attardo, S. (2001). Humorous Texts: A Semantic and Pragmatic Analysis. New York, Berlin: Mouton de Gruyter.

Bakhtin, M. (1968). Rabelais and His World. Cambridge, Mass.: MIT Press.

Bakhtin, M. (1994 [1981]). The Dialogic Imagination. Austin: University of Texas Press. 
Cegala, D. J. (1987). Persuasive Communication: Theory and Practice (3rd ed.). Edina, Mn: Burgess International.

Dave, L. (2008). Subliminal Persuasion. New Jersey: John Wiley \& Sons, Inc.

Davis, W. (1998). Implicature. Cambridge: Cambridge University Press. http://dx.doi.org/10.1017/CBO9780511663796

Eco, U. (1980). The Name of the Rose. English Translation (1983) by Harcourt, Inc. and Martin Secker \& Warburge Limited.

Geybels, H. (2011) The Redemptive Power of Humour in Religion. In H. Geybels, \& W. van Herck (Eds.), Humour and Religion: Challenges and Ambiguities. Proceedings of a Congress, 20-21 April 2009, University Centre Saint Ignatius Antwerp.

Gilhus, I. S. (1997). Laughing Gods, Weeping Virgins: Laughter in the History of Religion. London: Routledge. http://dx.doi.org/10.4324/9780203411605

Grice, P. (1975). Logic and Conversation. In P. Cole, \& J. Morgan (Eds.), Syntax and Semantics, Vol. 3, New York: Academic Press.

Herrick, A. J. (2012). The History and Theory of Rhetoric. London: Routledge.

Joeckel, S. (2008). Funny as Hell: Christianity and Humor Reconsidered. HUMOR: International Journal of Humor Research, 21, 415-433. http://dx.doi.org/10.1515/humr.2008.020

Kennedy, G. A. (2007). Aristotle, on Rhetoric: A Theory of Civic Discourse, Translated with Introduction, Notes and Appendices (2nd ed.). Oxford: Oxford University Press.

Koestler, A. (1964). The Act of Creation. London: Hutchinson \& Co.

Lakoff, R. (1982). Persuasive Discourse and Ordinary Conversation, with Examples from Advertising. In D. Tannen (Ed.), Analyzing Discourse: Text and Talk (pp. 25-42). Washington DC: Georgetown University Press.

Levinson, S. C. (1983). Pragmatics. Cambridge: Cambridge University Press.

Marciniak, P. (2011). Laughing against All the Odds. Some Observations on Humour, Laughter and Religion in Byzantium. In H. Geybels, \& W. van Herck (Eds.), Humour and Religion: Challenges and Ambiguities (pp. 141-155). London: Continuum.

McGhee, P. E. (1979). Humor: Its Origin and Development. San Francisco, CA: Freeman.

McQuarrie, E., \& Mick, D. G. (1996). Figures of Rhetoric in Advertising Language. Journal of Consumer Research, 22, 424-438. http://dx.doi.org/10.1086/209459

Mills, H. (2000). Artful Persuasion: How to Command Attention, Change Minds, and Influence People. New York: AMACOM.

Mindess, H. (1971). Laughter and Liberation. Los Angeles, CA: Nash.

Murphy, J. J. (2006). Rhetoric: History. In J. L. Mey (Ed.), (2009) The Concise Encyclopedia of Pragmatics (2nd ed., pp. 864-867). Oxford: Elsevier Ltd.

Palmer, E. F. (2001). The Humor of Jesus. Vancouver: Regent College Publishing.

Perloff, R. M. (1993). The Dynamics of Persuasion. London: Lawrence Erlbaum Associates Inc. Publishers.

Raskin, V. (1985). Semantic Mechanisms of Humor. Dordrecht-Boston-Lancaster: D. Reidel.

Ross, A. (2005). The Language of Humour. London: Routledge.

Samra, C. (1986). The Joyful Christ, the Healing Power of Humor. San Francisco, CA: Harper \& Row, Publishers.

Tannen, D. (1990). Rethinking Power and Solidarity in Gender and Dominance. Berkeley Linguistics Society, 16, 519-529. http://dx.doi.org/10.3765/bls.v16i1.3433

Trueblood, E. (1964). The Humour of Christ. London: Darton, Longman \& Todd Ltd.

Walton, D. (2007). Fundamentals of Critical Argumentation. Cambridge: Cambridge University Press.

Wood, R. (1988). The Comedy of Redemption: Christian Faith and Comic Vision in Four American Novelists. Notre Dame, IN: Notre Dame Press. 